\title{
Niepełnosprawność jako Inność - postawy studentów pełnosprawnych wobec studentów z niepełnosprawnością
}

Streszczenie: Na sytuację życiową osób z niepełnosprawnością, poza czynnikami indywidualnymi, ekonomicznymi czy prawnymi, oddziałują dominujące w społeczeństwie zachowania i nastawienia wobec nich (Ostrowska, 1997). W artykule wykorzystano wyniki badań własnych (Kapias, 2017), których celem było poznanie deklarowanych postaw studentów pełnosprawnych wobec studentów z niepełnosprawnością oraz poznanie opinii studentów niepełnosprawnych na ten temat, a także ustalenie różnic i podobieństw pomiędzy nimi. Badania były prowadzone metodą sondażu diagnostycznego, a wzięło w nich udział 116 studentów pełnosprawnych oraz 108 studentów z niepełnosprawnością. Ze względu na obszerność badań artykuł traktuje jedynie o deklaracjach studentów pełnosprawnych. Na podstawie zebranych danych można stwierdzić, iż najczęściej deklarowaną postawą wobec niepełnosprawności jako Inności była postawa ambiwalentna, a postawy negatywne należały do mniejszości.

Słowa kluczowe: niepełnosprawność jako Inność, postawy, student, edukacja międzykulturowa

\section{Wprowadzenie}

Osoby z niepełnosprawnością w Polsce wciąż są gorzej wykształcone w porównaniu z osobami sprawnymi, można jednak zaobserwować stały wzrost liczby studentów z niepełnosprawnością (Garbat i Paszkowicz, 2015). Od 2011 szkoły wyższe mają obowiązek stworzyć studentom z niepełnosprawnością odpowiednie warunki (MNiSW, 2011). Najtrudniejszymi barierami do pokonania są jednak bariery mentalne, które mogą generować sytuacje trudne ze względów emocjonalnych i komunikacyjnych zarówno dla studentów, jak i wykładowców (Marciniak, 2010; Kilian, 2016; Imiołczyk, Błaszczak i in. 2015). Studia dla osób z niepełnosprawnością są częścią procesu rehabilitacji społecznej i zawodowej (Skalska, 2015). Pozytywne postawy grupy studentów 
wobec studentów z niepełnosprawnością są ważnym elementem wspierającym te procesy. Józef Sowa (2004) uważa, że bardzo istotne dla rozwoju każdego studenta są odpowiednie relacje, które umożliwiają zaspokajanie podstawowych potrzeb społecznych oraz przyczyniają się do rozwoju w innych obszarach, np. intelektualnym. Budowanie dobrych relacji nie jest możliwe bez właściwych postaw wobec siebie nawzajem. Badanie postaw studentów pełnosprawnych wobec studentów z niepełnosprawnością jest zatem nadal ważne i potrzebne.

\section{Postawy wobec osób z niepełnosprawnością}

Współcześnie najczęściej przyjmowaną jest biopsychospołeczna koncepcja niepełnosprawności, która łączy w sobie jej wymiar indywidualny i społeczny (Majewski, 1999). Opiera się ona na trzech podstawowych założeniach: człowiek jest istotą biologiczną, społeczną i osobą. Światowa Organizacja Zdrowia (WHO) za niepełnosprawne uważa „osoby, które nie mogą, częściowo lub całkowicie, zapewnić sobie możliwości samodzielnego życia indywidualnego i społecznego, na skutek wrodzonego lub nabytego upośledzenia sprawności fizycznych i/lub psychicznych (Wilmowska-Pietruszyńska i Bilski, 2013, s. 7). Zgodnie z rozróżnieniem Jacka Kurzępy (2010) Inność odnosi się do cech fizycznych, psychicznych oraz zachowań uwarunkowanych obiektywnie, zatem można przyjąć, iż Inność wynikająca z niepełnosprawności oraz postawy wobec niej wpisują się w zainteresowania edukacji międzykulturowej.

Poprzez postawę rozumie się pewną utrzymującą się tendencję do wartościowania kogoś lub czegoś w określony sposób (Grabowski, 2007). Postawa to "trwały system pozytywnych ocen, uczuć emocjonalnych i pozytywnych lub negatywnych tendencji do zachowania się wobec przedmiotów społecznych (Mądrzycki, 1977). Przedmiotem postawy może być wszystko, co istnieje dla człowieka - podmiotu postawy (Marody, 1976). Przyjmując teorię strukturalną postaw, należy zaznaczyć, iż jest ona wewnętrzną relacją składników (komponentów), które je tworzą (Nowak, 1973; Marody, 1976; Mądrzycki, 1977). Na komponent poznawczy składają się wiedza oraz przekonania podmiotu postawy na temat przedmiotu postawy. Komponent afektywny obejmuje uczucia, jakie obiekt postawy wzbudza w podmiocie postawy. Może on wyrażać się w emocjach pojawiających się na widok lub wyobrażenie podmiotu postawy (np. radość, pogarda, lęk, szacunek). W obrębie komponentu behawioralnego znajdują się dyspozycje do zachowania wobec obiektu postawy w określony sposób. 
Liczne opracowania teoretyczne wskazują na dużą złożoność etiologii postaw społecznych w szczególności względem osób z niepełnosprawnością. Podstawowe czynniki warunkujące ukształtowanie się jakiejś postawy to elementy związane z przedmiotem i podmiotem postawy oraz uwarunkowania środowiskowe (Mądrzycki, 1977). Jednym z czynników związanych z osobą będącą przedmiotem postawy może być wygląd zewnętrzny, czyli m.in. stopień, w jakim niepełnosprawność jest widoczna, ubiór, stan uzębienia, uczesanie (Larkowa, 1980). Duże znaczenie ma również pierwszy kontakt, cechy, jakie osoba ujawni w jego trakcie. Według niektórych badaczy istotne w procesie kształtowania się postaw są samoocena (Sękowski, 1994), stopień zrehabilitowania i samodzielności osoby z niepełnosprawnością oraz jej aktywność i sposoby przezwyciężania trudności (Chodkowska i Kazanowski, 2007). Wśród czynników związanych z podmiotem postawy są m.in. wiek, płeć, poziom ogólnej wiedzy oraz tej z zakresu dotyczącego przedmiotu postawy, a także cechy osobowościowe. A. Sękowski (1994) zwraca uwagę na poziom kultury osobistej podmiotu postawy, poziom inteligencji oraz zdolności twórcze. Czynnikiem determinującym postawę wobec osób z niepełnosprawnością może być również lęk przed odmiennością oraz brak osobistych doświadczeń w kontaktach z osobami z niepełnosprawnością (Wolska-Zogata, 2012). Wśród czynników środowiskowych można wyróżnić czynniki ekonomiczne, kulturowe, w tym religijne, postawy dominujące w otoczeniu podmiotu postawy np. w rodzinie (Mądrzycki, 1977) oraz funkcjonujące w społeczeństwie stereotypy (Wolińska, 2015).

Istnieje wiele klasyfikacji postaw wobec osób z niepełnosprawnością. Zazwyczaj mówi się o postawach negatywnych (jawnie odrzucających lub ukrytych), pozytywnych (akceptujących), obojętnych lub ambiwalentnych (Zasępa, 2005; Grabowski, 2007; Granofsky za Sękowski, 1994; Kowalewski, 1995). Biorąc pod uwagę złożoność i wielowymiarowość kategorii postaw, można przyjąć bardziej rozbudowaną klasyfikację postaw wobec osób z niepełnosprawnością zaproponowaną przez Chodkowską i Kazanowskiego (2007), którzy wyróżniają postawę pełnej akceptacji, częściowej akceptacji, quasi-akceptacji, ambiwalencji, lekceważenia, niechęci oraz wrogości.

Tabela 1. Charakterystyka postaw wobec osób z niepełnosprawnością

\begin{tabular}{|l|l|}
\hline \multicolumn{1}{|c|}{ Postawa } & \multicolumn{1}{c|}{ Charakterystyka } \\
\hline $\begin{array}{l}\text { pełna } \\
\text { akceptacja }\end{array}$ & $\begin{array}{l}\text { adekwatna wiedza o osobach z niepełnosprawnością, } \\
\text { pozytywny stosunek emocjonalny wobec działań mających na celu integrację osób z nie- } \\
\text { pełnosprawnością z resztą społeczeństwa (nie tylko okazjonalne kontakty) }\end{array}$ \\
\hline
\end{tabular}




\begin{tabular}{|l|l|}
\hline $\begin{array}{l}\text { częściowa } \\
\text { akceptacja }\end{array}$ & $\begin{array}{l}\text { niekompletna postawa, w której nie wszystkie komponenty są rozwinięte w sposób wy- } \\
\text { starczający, } \\
\text { brak adekwatnej wiedzy o możliwościach i potrzebach osób z niepełnosprawnością, } \\
\text { okazjonalne interakcje }\end{array}$ \\
\hline $\begin{array}{l}\text { quasi- } \\
\text {-akceptacja }\end{array}$ & $\begin{array}{l}\text { natrętna ciekawość, } \\
\text { narzucanie opieki, } \\
\text { wyręczanie, } \\
\text { nieuzasadnione współczucie, } \\
\text { litość }\end{array}$ \\
\hline ambiwalencja & $\begin{array}{l}\text { stosunek emocjonalny jest zależny od okoliczności, } \\
\text { interakcje są zróżnicowane i zależą od rodzaju i stopnia niepełnosprawności, } \\
\text { pozytywne deklaracje nt. kontaktów z osobami z niepełnosprawnością, } \\
\text { unikanie kontaktów, w których należałoby wziąć na siebie współodpowiedzialność za po- } \\
\text { trzeby danej osoby }\end{array}$ \\
\hline lekceważenie & $\begin{array}{l}\text { ocenianie problemów osób z niepełnosprawnością za nieistotne, } \\
\text { unikanie kontaktów }\end{array}$ \\
\hline niechęć & $\begin{array}{l}\text { wiedza ograniczona do tej dotyczácej słabości i ograniczeń osób z niepełnosprawnością, } \\
\text { negatywna ocena przywilejów osób z niepełnosprawnością, } \\
\text { niechęć do kontaktów }\end{array}$ \\
\hline wrogość & $\begin{array}{l}\text { przeświadczenie, że osoby z niepełnosprawnością są „ciężarem dla rodziny i społeczeństwa”, } \\
\text { preferowanie gettyzacji }\end{array}$ \\
\hline
\end{tabular}

Źródło: opracowanie własne na podstawie: M. Chodkowska, Z. Kazanowski: Socjopedagogiczne konteksty postaw nauczycieli wobec edukacji integracyjnej, s. 21.

\section{Metodologia badań własnych}

Celem badań było poznanie deklarowanych postaw studentów pełnosprawnych wobec studentów z niepełnosprawnością oraz poznanie opinii studentów niepełnosprawnych na ten temat, a także ustalenie różnic i podobieństw pomiędzy nimi.

Niniejszy artykuł zawiera jedynie wycinek badań dotyczący deklarowanych postaw studentów pełnosprawnych. Pytania badawcze odnoszące się do tej części badania zbudowane zostały na podstawie trzech komponentów postaw:

1. Jakie poglądy, opinie, przekonania dotyczące studentów z niepełnosprawnością deklarują studenci pełnosprawni?

2. Jakie uczucia dotyczące studentów z niepełnosprawnością deklarują studenci pełnosprawni?

3. Jakie działania wobec studentów z niepełnosprawnością deklarują studenci pełnosprawni?

W badaniach zastosowano strategię ilościową. Metodami właściwymi do badania opinii, tendencji i postaw są badania sondażowe (Creswell, 2013), 
w związku z czym w badaniach zastosowano metodę sondażu diagnostycznego w postaci ankiety.

Grupę badaną stanowiło 116 studentów z 18 polskich uczelni. Wśród badanych 40 osób $(34,5 \%)$ studiuje w jednej grupie z osobą z niepełnosprawnością, a 16 osób badanych (13,8\%) nie zna osobiście żadnej takiej osoby.

Należy pamiętać, że zebrane dane są jedynie deklaracjami. Ze względu na dużą ilość zebranego materiału przytoczę jedynie przykłady odpowiedzi na wybrane pytania oraz uogólnione wyniki.

\section{Wyniki badań własnych}

Jednym z trzech komponentów postawy jest komponent poznawczy (Nowak, 1973; Marody, 1976; Mądrzycki, 1977) obejmujący wiedzę na temat przedmiotu postawy oraz opinie i przekonania. Część pytań kwestionariusza dotycząca tego komponentu zawierała jedno pytanie otwarte na temat znajomości rodzajów niepełnosprawności oraz kilka pytań zamkniętych, które przyjęły formę zdań, do których badani mieli się ustosunkować, zaznaczając jedną z odpowiedzi: „zgadzam się”, „raczej się zgadzam”, „trudno powiedzieć”, „raczej się nie zgadzam”, „nie zgadzam się”. Przykładem może być sformułowanie "niewidomi mogą obsługiwać komputery”. Ze zdaniem tym zgodziło się $78,4 \%$ badanych, a $12 \%$ wybrało odpowiedź „raczej się zgadzam”.

Wykres 1. Poznawczy aspekt postaw studentów pełnosprawnych wobec studentów z niepełnosprawnością - odpowiedzi na przykładowe pytania

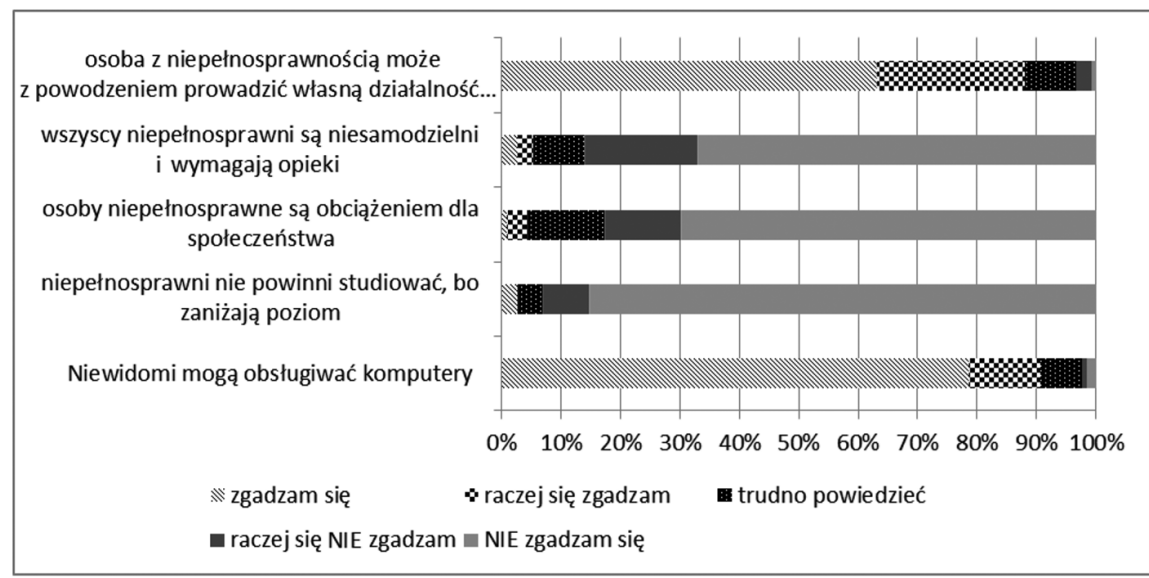

Źródło: badania własne. 
Odpowiedzi na niektóre pytania zestawiono ze sobą, celem bardziej dogłębnej analizy danych. 19,8\% badanych wybrało opcję "zgadzam się" przy dwóch bardzo różnych opiniach: „niektórzy niepełnosprawni są zgorzkniali i użalają się nad sobą” oraz „niektórzy niepełnosprawni potrafią żartować ze swojej dysfunkcji”. Fakt ten pozwala przypuszczać, że są to osoby niemyślące stereotypowo, zdające sobie sprawę z tego, iż osoby z niepełnosprawnością bardzo się między sobą różnią.

Na podstawie zebranych danych opracowano dwa wyniki zbiorcze - jeden dotyczący wiedzy, drugi odnoszący się do opinii i przekonań. Całkowity brak wiedzy stwierdzono u $5,2 \%$ osób, niski u 22,4\%, przeciętny u $31 \%$ badanych, a powyżej przeciętnej u 41,4\% osób. Poglądy i opinie typowe dla postaw negatywnych stwierdzono u zaledwie 1,7\% badanych, a poglądy $0,9 \%$ badanych zaklasyfikowano jako bliższe postawom negatywnym. Poglądy neutralne stwierdzono u $12 \%$ osób. U zaskakująco dużej liczby respondentów stwierdzono poglądy i opinie typowe dla postaw pozytywnych $-44,8 \%$ lub im bliskie $-40,5 \%$.

Wykres 2. Ocena deklarowanej wiedzy, opinii i przekonań studentów pełnosprawnych wobec osób z niepełnosprawnością

Wiedza

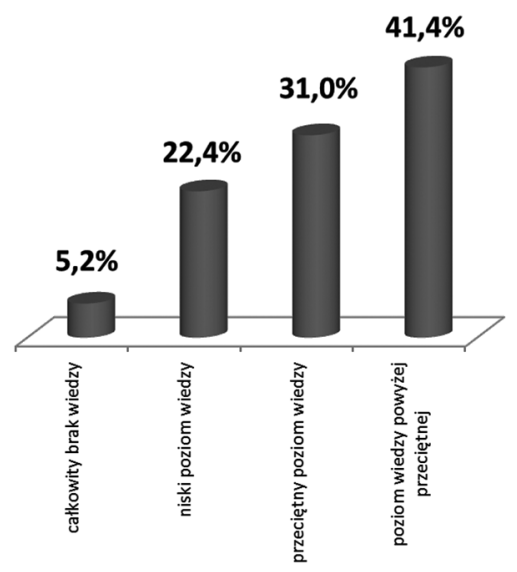

Opinie i przekonania

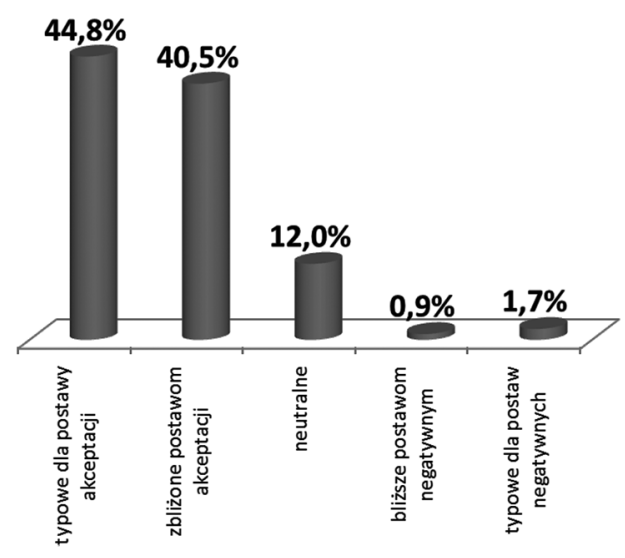

Źródło: badania własne.

Na podstawie zaprezentowanych danych można sformułować wniosek, iż większość badanych posiada wiedzę na temat osób z niepełnosprawnością 
na poziomie przeciętnym lub powyżej przeciętnej, podobnie opinie i przekonania badanych na temat osób z niepełnosprawnością w większości są typowe dla postawy akceptacji lub im bliskie. Warto zwrócić również uwagę, że badani, którzy wykazywali niski poziom wiedzy, często deklarowali poglądy przychylne osobom z niepełnosprawnością, ale u trzech osób, które prezentują bardzo negatywne poglądy, stwierdzono jednocześnie brak wiedzy na ich temat.

Zachowania podmiotu postawy wobec jej przedmiotu wpisują się w komponent behawioralny (Nowak, 1973; Marody, 1976; Mądrzycki, 1977). Respondenci zostali poproszeni o zadeklarowanie w jaki sposób zachowaliby się lub zachowują się w określonej sytuacji kontaktu z osobami z niepełnosprawnością. Przykładem zdania, do którego mieli odnieść się badani, może być: „Pożyczyłbym notatki niepełnosprawnemu koledze, tak samo jak innym", z którym zgodziła się znaczna część respondentów - 93,1\%. Bardziej zróżnicowane są odpowiedzi, które dotyczą bliższej relacji aniżeli incydentalnego spotkania. Przy stwierdzeniu: „Mógłbym/mogłabym mieć za żonę/ męża osobę z niepełnosprawnością” odpowiedź „zgadzam się" wybrało 19\%, a „raczej się zgadzam” wybrało 22,4\%. Najczęściej padała odpowiedź „trudno powiedzieć" (42,2\%). Wprost nie zgadza się 8,6\% osób, a opcję „raczej się nie zgadzam" wybrało $7,8 \%$ badanych.

Wykres 3. Behawioralny aspekt postaw studentów pełnosprawnych wobec studentów z niepełnosprawnością - odpowiedzi na przykładowe pytania

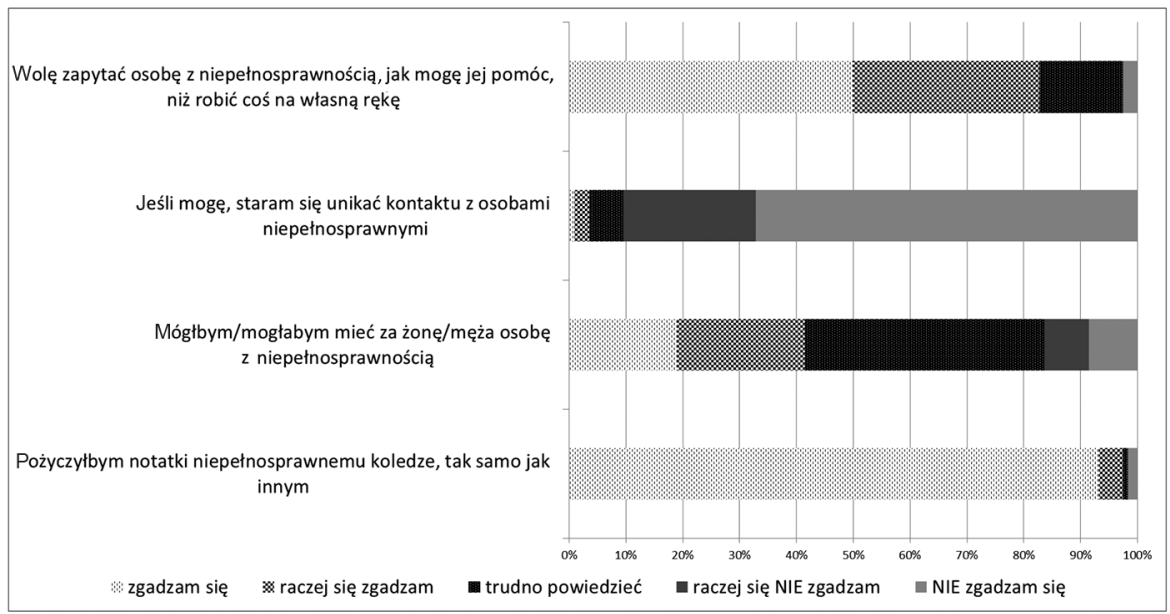

Źródło: badania własne. 
Przywołując wspomnianą klasyfikację postaw, część odpowiedzi świadczy o ambiwalencji. Badani często składają pozytywne deklaracje nt. kontaktów $\mathrm{z}$ osobami z niepełnosprawnością, ale w sytuacjach, w których należałoby wziąć na siebie współodpowiedzialność za drugą osobę, deklaracje nie są już takie oczywiste. Unikanie kontaktu z osobami z niepełnosprawnością (Wykres 3) jest przyporządkowane postawom nacechowanym negatywnie.

Wykres 4. Ocena deklarowanych zachowań studentów pełnosprawnych wobec osób z niepełnosprawnością

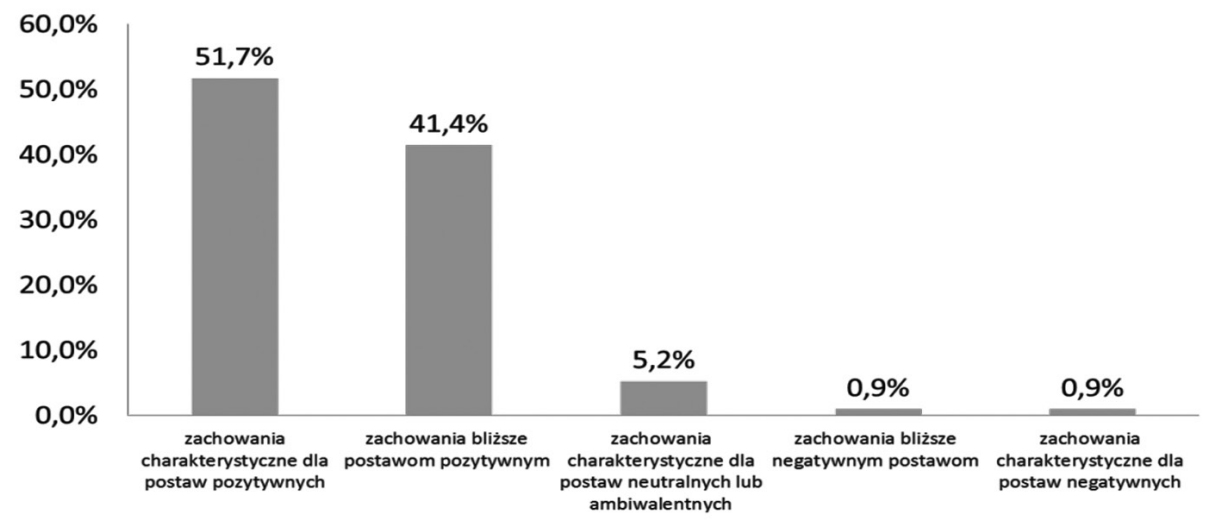

Źródło: badania własne.

Po przeanalizowaniu wszystkich odpowiedzi pod kątem obranych kryteriów można stwierdzić, iż ponad połowa badanych $(51,7 \%)$ deklarowała zachowania charakterystyczne dla postaw pozytywnych lub im zbliżone $(41,4 \%)$. Zachowania charakterystyczne dla postaw neutralnych lub ambiwalentnych przeważały u 5,2\% osób, natomiast bliższe negatywnym i negatywne pojawiły się łącznie u 1,7\% badanych. Część badanych, którzy posiadają przeciętną wiedzę lub wiedzę poniżej przeciętnej oraz deklarują opinie i przekonania nie zawsze w pełni akceptujące, w przypadku kontaktu z osobami z niepełnosprawnością zachowują się lub zachowaliby się w sposób charakterystyczny dla postaw akceptujących.

Nieco inaczej prezentują się wyniki w zakresie komponentu afektywnego. Za przykład może posłużyć sformułowanie: „W kontaktach z osobami niepełnosprawnymi boję się, że czymś ich urażę". Z takim stwierdzeniem zgodziło się 11,2\% osób, a opcję „raczej się zgadzam” wybrało 35,3\% badanych. 
Wykres 5. Afektywny aspekt postaw studentów pełnosprawnych wobec studentów z niepełnosprawnością - odpowiedzi na przykładowe pytanie „osoby niepełnosprawne wzbudzają we mnie..."

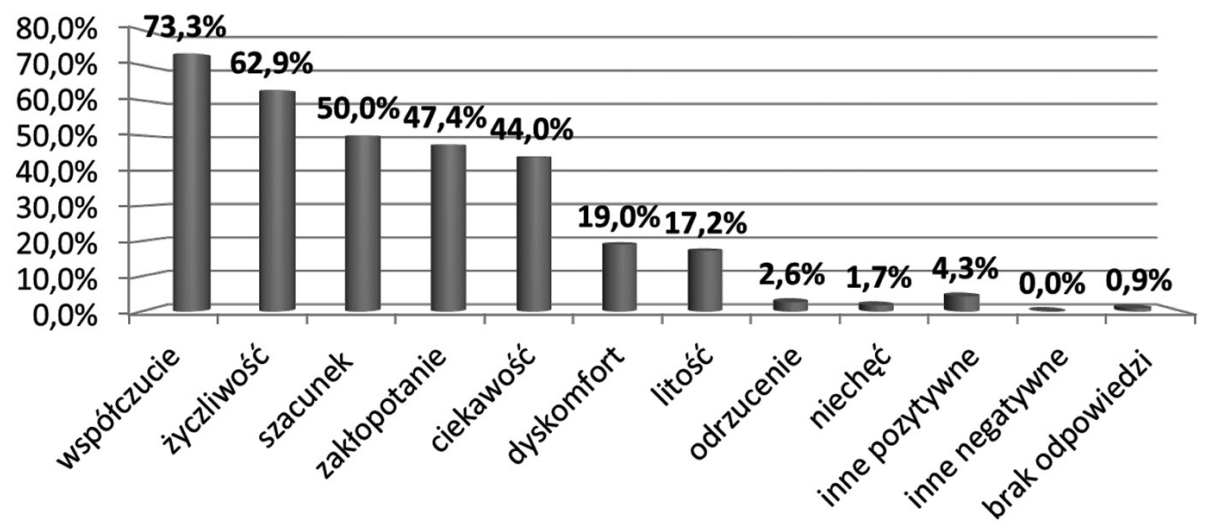

Źródło: badania własne.

W ostatnim pytaniu respondenci zostali poproszeni o dokończenie zdania. Najczęściej pojawiającą się odpowiedzią było współczucie (73,3\%), następnie życzliwość (62,9\%), szacunek (50\%), zakłopotanie (47,4\%), ciekawość (44\%), dyskomfort (19\%), litość $(17,2 \%)$, odrzucenie $(2,6 \%)$, niechęć $(1,7 \%)$ oraz 4,3\% innych odpowiedzi zaklasyfikowanych, jako pozytywne (w rubryce „inne”). Część respondentów w odpowiedzi na powyższe pytanie zaznaczyła zarówno odpowiedzi charakteryzujące postawy pozytywne, jak i negatywne, co świadczy o ambiwalencji uczuć i emocji, które pojawiają się w kontaktach $\mathrm{z}$ osobami z niepełnosprawnością. Potwierdza to zestawienie prezentowane na wykresie 6, który zawiera ogólną ocenę afektywnego komponentu postawy studentów pełnosprawnych wobec osób z niepełnosprawnością.

Uogólniając, deklaracje badanych wskazywały na uczucia i emocje uznawane za pozytywne (łącznie 51,7\% osób). Pozostałe deklaracje zostały zakwalifikowane jako świadczące o postawie ambiwalentnej (37\%) oraz nacechowane negatywnie (10,3\%). Przywołując jeszcze raz wyniki dotyczące komponentów poznawczego i behawioralnego, można zauważyć, że w przypadku komponentu afektywnego więcej badanych zakwalifikowano do postaw bliższych negatywnym. 
Wykres 6. Ocena deklarowanych emocji i uczuć studentów pełnosprawnych wobec osób z niepełnosprawnością

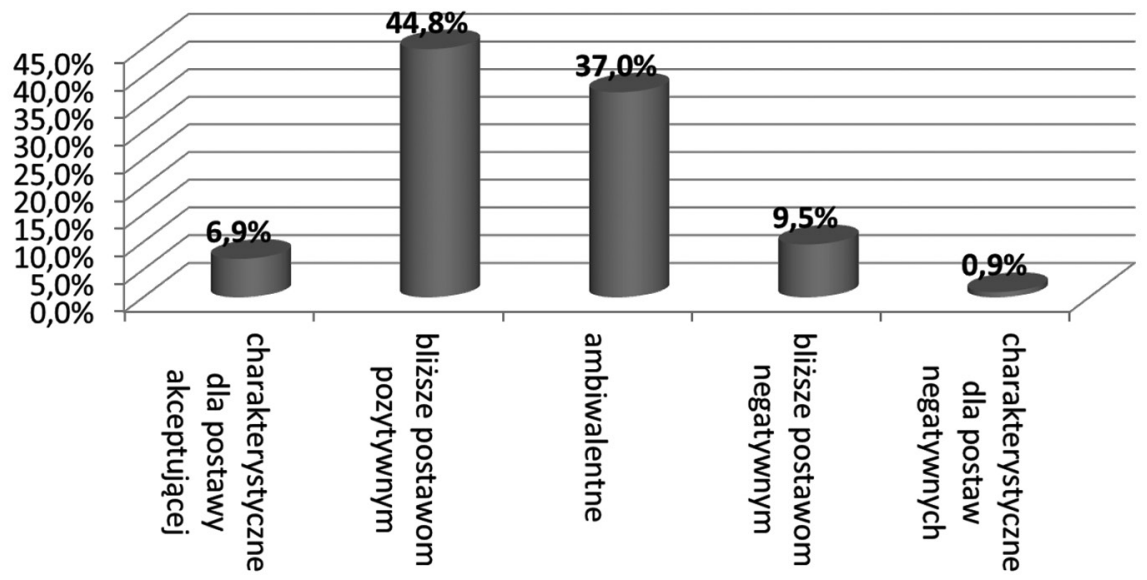

Źródło: badania własne.

Tabela 2. Zestawienie wyników zbiorczych trzech komponentów postawy z zakresie deklaracji charakterystycznych dla postaw negatywnych i im bliższych

\begin{tabular}{|l|c|c|c|}
\hline & $\begin{array}{c}\text { Komponent poznawczy } \\
\text { (opinie i przekonania) }\end{array}$ & $\begin{array}{c}\text { Komponent } \\
\text { behawioralny }\end{array}$ & $\begin{array}{c}\text { Komponent } \\
\text { afektywny }\end{array}$ \\
\hline $\begin{array}{l}\text { bliższe postawom } \\
\text { negatywnym }\end{array}$ & $0,9 \%$ & $0,9 \%$ & $\mathbf{9 , 5 \%}$ \\
\hline $\begin{array}{l}\text { charakterystyczne } \\
\text { dla postaw negatywnych }\end{array}$ & $1,7 \%$ & $0,9 \%$ & $0,9 \%$ \\
\hline
\end{tabular}

Źródło: badania własne.

Jak wynika z zestawienia prezentowanego w tabeli 2, część badanych w zakresie komponentów poznawczego i behawioralnego nie deklarowała opinii, przekonań i zachowań charakterystycznych dla postaw negatywnych lub im bliższych, ale zadeklarowała odpowiadające im emocje i uczucia. Świadczyć to może o braku wewnętrznej spójności postawy u części badanych.

Postawę można scharakteryzować za pomocą takiej cechy jak złożoność, tzn. poszczególne komponenty postawy mogą być w różnym stopniu rozwinięte (Mądrzycki, 1977). W związku z powyższym analiza zbiorcza danych w zakresie każdego z komponentów nie jest wystarczająca do odpowiedzi na pytanie, jakie są deklarowane postawy studentów z niepełnosprawnością. Dokonano zatem szczegółowej analizy każdej z ankiet z uwzględnieniem kryteriów wynikających z kategorii postaw zaproponowanych przez Chodkowską 
i Kazanowskiego (2007). Na tej podstawie można stwierdzić, że w grupie badanej znalazło się 13,8\% osób wykazujących postawę pełnej akceptacji wobec osób z niepełnosprawnością. Następnie częściową akceptację stwierdzono u 19 badanych, a quasi-akceptację u 10,3\%. Postaw negatywnych było zdecydowanie mniej. Wrogość wobec osób niepełnosprawnych zadeklarowało $0,9 \%$ osób, niechęć $2,6 \%$ i postawę lekceważącą $3,4 \%$ badanych. Postawy pozostałych $50 \%$ zostały zakwalifikowane, jako ambiwalentne.

Wykres 7. Deklarowane postawy badanych studentów pełnosprawnych wobec osób z niepełnosprawnością

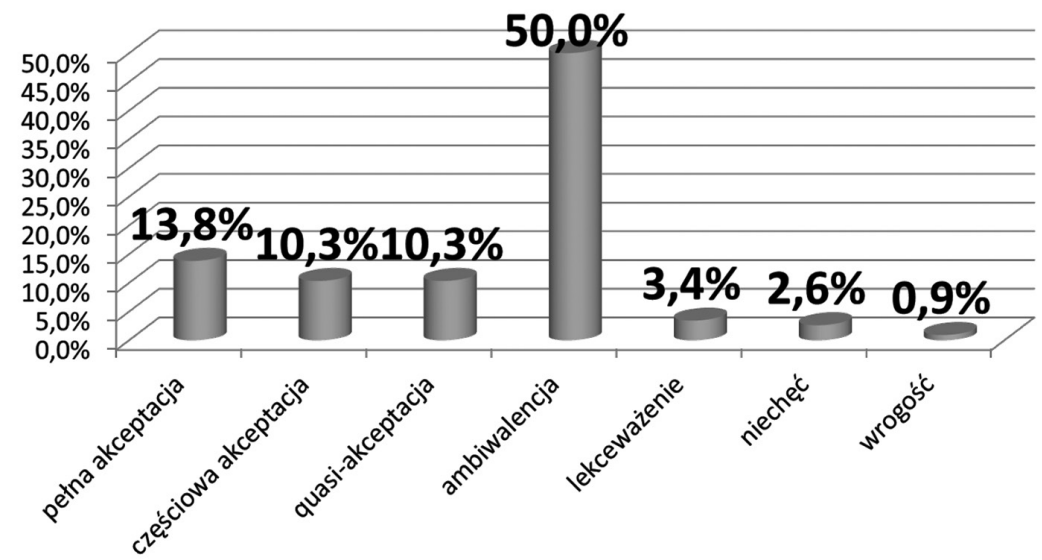

Źródło: badania własne.

Po szczegółowej analizie każdej z ankiet potwierdziło się przypuszczenie o wewnętrznym zróżnicowaniu postaw studentów pełnosprawnych wobec studentów z niepełnosprawnością. Pomimo że z analizy zbiorczej w ramach każdego z komponentów wynikało, że większość prezentuje postawy pozytywne lub im zbliżone, do grupy osób prezentujących postawę pełnej akceptacji zaliczyć można było zaledwie $13,8 \%$ badanych.

\section{Wnioski i podsumowanie}

Zarówno w zakresie komponentu poznawczego, jak i behawioralnego wśród badanych studentów pełnosprawnych dominują elementy charakterystyczne dla postaw pozytywnych, akceptujących lub im bliskie. Inaczej jest w przypadku komponentu afektywnego, gdzie najczęściej deklarowane są emocje 
i uczucia ambiwalentne lub zbliżone do pozytywnych, natomiast charakterystyczne dla postaw akceptujących należą do mniejszości. Z deklaracji wynika również, iż postawy skrajnie negatywne należą do mniejszości, jednak wciąż incydentalnie się pojawiają. Deklaracje połowy badanych wskazują na ambiwalencję postaw wobec studentów $\mathrm{z}$ niepełnosprawnością, nie są one wewnętrznie spójne, często są nacechowane zarówno współczuciem, jak i życzliwością. Postawę skrajnie pozytywną, jaką jest pełna akceptacja, zadeklarowało niespełna 14\% badanych. Można zatem wysnuć wniosek, że wciąż jest to pole działania również dla praktyków edukacji międzykulturowej. Postawy są czymś trwałym, trudnym do zmiany, jednakże wskazane są działania umożliwiające ich modelowanie, które powinny być szczególnie skierowane na komponent afektywny. Emocje i uczucia, takie jak współczucie, litość, lęk, nie sprzyjają prawidłowym relacjom pomiędzy studentami pełnosprawnymi i z niepełnosprawnością. Warto byłoby poświęcić czas na tworzenie okazji do spotkania z Innym, w takich okolicznościach, aby mogły urzeczywistnić się po obu stronach pozytywne emocje.

\section{Bibliografia}

Chodkowska, M. i Kazanowski, Z. 2007. Socjopedagogiczne konteksty postaw nauczycieli wobec edukacji integracyjnej. Lublin: UMCS.

Creswell, J. W. 2013. Projektowanie badań naukowych - metody jakościowe, ilościowe i mieszane. Kraków: UJ.

Garbat, M. i Maszkowicz, M. A. 2015. Studenci z niepełnosprawnościami na polskich uczelniach. Studia Oeconomica Posnaniensia. 3 (10), ss. 113-130.

Grabowski, A. 2007. Ambiwalencja postaw interpersonalnych w sytuacji statego kontaktu i po jego zakończeniu. Kraków: Oficyna Wydawnicza „Impuls".

Imiołczyk, B., Błaszczak, A. i wsp. 2015. Dostępność edukacji akademickiej dla osób z niepełnosprawnościami - analiza i zalecenia. Prawo i Praktyka. 16, ss. 46-56.

Kapias, J. 2017. Postawy studentów petnosprawnych wobec studentów $z$ niepetnosprawnościq a opinie studentów z niepetnosprawnościa na ten temat. Promotor: prof. zw. dr hab. Zenon Gajdzica. Cieszyn: UŚ. Praca licencjacka niepublikowana.

Kilian, M. 2016. Studenci z niepełnosprawnościami: doświadczenia, potrzeby, wyzwania. Forum Pedagogiczne. 1, ss. 267-282. 
Kowalewski, L. 1995. Psychologiczna i społeczna sytuacja dzieci niepełnosprawnych. W: Obuchowska, I. red. Dziecko niepetnosprawne w rodzinie. Warszawa: WSIP, ss. 55-100.

Kurzępa, J. 2010. Doświadczenie Inności/Odmienności w perspektywie socjoedukacyjnej. W: Lewowicki, T. i Ogrodzka-Mazur, E. red. Edukacja międzykulturowa - teorie, poglady, doświadczenia spoteczne. Toruń: Wydawnictwo Adam Marszałek, ss. 217-234.

Larkowa, H. 1980. Postawyspołeczne wobec osób z odchyleniami od normy. W: Hulek, A. red. Pedagogika rewalidacyjna. Warszawa: PWN, ss. 478-491 .

Majewski, T. 1999. Biopsychospołeczna koncepcja niepełnosprawności. Szkota Specjalna. 3, ss. 131-134.

Marciniak, A. 2010. Biblioteka akademicka w służbie osobom niepełnosprawnym. Pomoc w zdobywaniu dodatkowych umiejętności, Bibliotheca Nostra. 1, ss. 72-83.

Marody, M. 1976. Sens teoretyczny a sens empiryczny pojęcia postawy - analiza metodologiczna zasad doboru wskaźników w badaniach nad postawami. Warszawa: PWN.

Mądrzycki, T. 1977. Psychologiczne prawidtowości ksztattowania się postaw. Warszawa: WSiP.

MNiSW, 2011. https://www.gov.pl/web/nauka/wsparcie-niepelnosprawnychstudentow-i-doktorantow (25.06.2019).

Nowak, S. 1973. Pojęcie postawy w teoriach i stosowanych badaniach społecznych. W: Nowak, S. red. Teorie postaw. Warszawa: PWN, ss. 17-88.

Ostrowska, A. 1997. Postawy społeczeństwa polskiego w stosunku do osób niepełnosprawnych. W: Gustavson, A. i Zakrzewska-Manterys, E. red. Upośledzenie w spotecznym zwierciadle. Warszawa: Wydwnictwo Edukacyjne „Żak”, ss. 75-95.

Sękowski, A. 1994. Psychologiczne determinanty postaw wobec inwalidów. Lublin: UMCS.

Sękowski, A. 1994. Wybrane koncepcje teoretyczne postaw wobec osób niepełnosprawnych. W: Chodkowska, M. red. Człowiek niepetnosprawny. Problemy autorealizacji i społecznego funkcjonowania. Lublin: UMCS, ss. 97-110. Skalska, K. 2018. Wsparcie społeczne a satysfakcja z życia studentów z niepełnosprawnościa. Student Niepetnosprawny. Szkice i Rozprawy. 8, ss. 119-136.

Sowa, J. 2004. Podmiotowość studenta w procesie kształcenia. W: Rumiński, A. red. Jakość życia studentów. Kraków: Oficyna Wydawnicza „Impuls", ss. 53-61. 
Wilmowska-Pietruszyńska, A. i Bilski, D. 2013. Międzynarodowa Klasyfikacja Funkcjonowania, Niepełnosprawności i Zdrowia. Niepełnosprawność Zagadnienia, Problemy, Rozwiązania. 11, ss. 5-20.

Wolińska, J. 2015. Percepcja społeczna, stereotyp niepełnosprawności - perspektywa aktora i obserwatora. Annales Universitatis Mariae Curie-Sktodowska. 1 (XXVIII), ss. 45-66.

Wolska-Zogata, I. 2012. Postawy społeczne wobec osób niepełnosprawnych przegląd badań. Współczesne Pielęgniarstwo i Ochrona Zdrowia. 4, ss. 81$-86$.

Zesępa, E., Starzomska, M. i Czabała, C. 2005. Postawy wobec niepełnosprawności i osób niepełnosprawnych. Człowiek - Niepetnosprawność Społeczeństwo. 1, ss. 23-36.

\title{
Disability as Otherness - the attitudes of students without disability to disabled students
}

\begin{abstract}
The life situation of persons with disabilities, apart from individual, economic or legal factors, is influenced by the prevailing behaviors and attitudes towards them in society (Ostrowska, 1997). The article was based on the own research (Kapias, 2017), whose aim was to learn the declared attitudes of students towards students with disabilities and to get the opinions of students with disabilities on the subject, as well as to find differences and similarities between them. The research was conducted using a diagnostic survey, and 116 non-disabled students and 108 students with disabilities participated in it. Due to the extensive nature of the research, the article treats only about the declarations of non-disabled students. On the basis the collected data, it can be stated that the most frequently declared attitude was an ambivalent attitude, and negative attitudes belonged to the minority.
\end{abstract}

Keywords: disability as Otherness, attitudes, student, intercultural education

Translated by Joanna Kapias 